\title{
A yeast with unusual sulphur amino acid metabolism
}

\author{
Malgorzata Piotrowska* and Andrzej Paszewski \\ Institute of Biochemistry and Biophysics, Polish Academy of Sciences, Rakowiecka 35, 02-532 Warsaw, Poland
}

(Received 10 July 1990; accepted 19 July 1990)

\begin{abstract}
A yeast strain highly resistant to propargylglycine (an inhibitor of cystathionine $\gamma$-lyase) was isolated from air. It was partially characterized, but it has not been identified with any known yeast species. Its sulphur amino acid metabolism differed from that of other fungi by the lack of the reverse transsulphuration pathway from methionine to cysteine, as no activity of cystathionine $\beta$-synthase or cystathionine $\boldsymbol{\gamma}$-lyase was found. The functional lack of

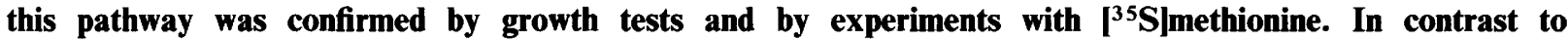
Saccharomyces cerevisiae neither homocysteine synthase nor the sulphate assimilation pathway were repressible by methionine in the new strain; on the contrary, a regulatory effect of cysteine was observed.
\end{abstract}

\section{Introduction}

An outline of sulphur amino acid metabolism is presented in Fig. 1. While the physiological importance of particular enzymic activities and regulatory patterns differs from species to species, in all fungi tested so far catabolism of methionine proceeds via the reverse transsulphuration pathway involving cystathionine $\beta$-synthase and cystathionine $\gamma$-lyase (steps 5 and 6). The strain described here lacks this pathway. The present report deals with this unusual metabolism and its regulation.

A preliminary report of part of this work was presented at the XIIth International Specialised Symposium on Yeast, Genetics of Non-conventional Yeast, Weimar 1987.

\section{Methods}

Strains. Strain PGR-13 is our isolate from air. Yeast strains used for comparison were: Saccharomyces cerevisiae haploid laboratory strain AT-12 (adel) and industrial diploid AS-4 (wild-type), Pachysolen tannophilus (wild-type) from our laboratory collection and Candida utilis Ct5 (wild-type) from the collection of the Institute of Fermentation Industry, Warsaw. $S$. cerevisiae strain cys 3 , impaired in cystathionine $\gamma$-lyase, was kindly supplied by Dr B. Ono.

Media and growth conditions. Preliminary characterization of strain PGR-13 was done by the methods and on the media described by Barnett et al. (1983).

For other experiments strains were grown on GO minimal medium as described by Swietlinska et al. (1978), supplemented as indicated. For enzyme assays the cultures were grown at $30^{\circ} \mathrm{C}$ on a rotary shaker (150 r.p.m.) and harvested in the exponential phase of growth.

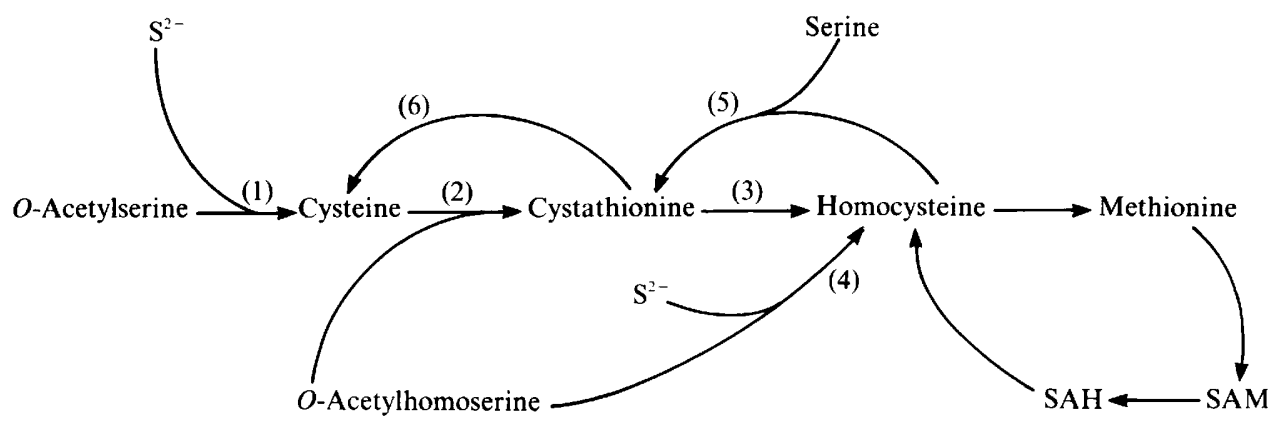

Fig. 1. An outline of sulphur amino acid metabolism in fungi. Enzymes: (1) cysteine synthase, (2) cystathionine $\gamma$-synthase, (3) $\beta$ cystathionase, (4) homocysteine synthase, (5) cysthathionine $\beta$-synthase, (6) cystathionine $\gamma$-lyase. SAM, $S$-adenosylmethionine; SAH, $S$-adenosylhomocysteine. 
Enzyme assays. Yeast cells were suspended in $0.1 \mathrm{~mm}$-potassium phosphate buffer pH 7.5 and disrupted in a Braun homogenizer. Cystathionine $\gamma$-lyase (EC 4.4.1.1) and $\beta$-cystathionase (EC 4.4.1.8) were assayed according to Paszewski \& Grabski (1974). Homocysteine synthase (EC 4.2.99.10) was assayed using the reaction mixture described by Paszewski \& Grabski (1973). Cystathionine $\beta$-synthase (EC 4.2.1.22) was assayed both as serine sulphydrylase and as cystathionine synthase using $\mathrm{DL}-\left[{ }^{14} \mathrm{C}\right]$ serine $[1.6 \mu \mathrm{Ci}(59.2 \mathrm{kBq})$ per reaction mixture] as described by Pieniazek et al. (1973). Protein was estimated by the method of Bradford (1976).

Determination of the pool of ${ }^{35} S$-labelled compounds. In experiments with ${ }^{35} \mathrm{SO}_{4}^{2-}$, cultures were grown in a modified medium in which the sulphate concentration was lowered to $2 \mathrm{mM}$ (substituting the corresponding chlorates for the sulphates omitted). The cells were grown under standard conditions for $6 \mathrm{~h}$, then $\mathrm{Na}_{2}{ }^{35} \mathrm{SO}_{4}\left(4.9 \times 10^{8}\right.$ c.p.m. $\mathrm{mmol}^{-1}$ ) was added and growth was continued. The cells were harvested at the early stationary phase and the labelled compounds isolated as described previously (Paszewski et al., 1984). Methionine was determined by thin-layer chromatography (TLC), and cysteine, glutathione and homocysteine by high-voltage paper electrophoresis as described earlier (Paszewski \& Grabski, 1974).

Methionine metabolism was studied in cells grown in GO medium supplemented with $\left.3 \mathrm{mM}-\mathrm{L}-{ }^{35} \mathrm{~S}\right]$ methionine $\left(3.6 \times 10^{8}\right.$ c.p.m. nmol $\left.{ }^{-1}\right)$. Growth conditions and determination of sulphur-labelled compounds were the same as in experiments with radioactive sulphate. Since $S$ adenosylmethionine decomposes during water extraction of cells at $100^{\circ} \mathrm{C}$, it was determined as 5-methylthioadenosine by TLC along with methionine. The amounts of radioactive substances were calculated from the specific activities of ${ }^{35} \mathrm{SO}_{4}^{2-}$ and $\mathrm{L}^{2}\left[{ }^{35} \mathrm{~S}\right]$ methionine, respectively.

Reagents. $O$-Acetylhomoserine was synthesized by the method of Wiebers \& Garner (1967). DL-Propargylglycines sodium selenate and Lamino acids were from Sigma. DL- $\left[{ }^{14} \mathrm{C}\right]$ Serine and $\mathrm{Na}_{2}{ }^{35} \mathrm{SO}_{4}$ were obtained from the Institute of Nuclear Research, Swierk, Poland. L$\left.{ }^{35} \mathrm{~S}\right]$ Methionine $\left(1000 \mathrm{Ci} \mathrm{mmol}{ }^{-1} ; 37 \mathrm{TBq} \mathrm{mmol}^{-1}\right)$ was from Amersham. On the day it was used, L- $\left[{ }^{35} S\right]$ methionine accounted for $83 \%$ of the total radioactivity of the preparation, as determined by TLC.

\section{Results and Discussion}

\section{Isolation and preliminary characterization of the strain}

During our work on effects of the antibiotic propargylglycine on enzymes of sulphur amino acid metabolism in fungi (Piotrowska \& Paszewski, 1986), we isolated from air a yeast strain, designated PGR-13, resistant to the antibiotic at concentrations up to $200 \mu \mathrm{M}$. The growth properties of the isolate did not correspond exactly to those of any yeast described by Barnett et al. (1983). Morphologically, it strongly resembled $S$. cerevisiae. However, $S$. cerevisiae is unable to utilize lysine and uracil as nitrogen sources, while PGR-13 utilized both.

\section{Sulphur amino acid metabolism of strain PGR-13}

The most striking trait of strain PGR-13 concerns its sulphur amino acid metabolism. When enzymes of methionine metabolism were examined, we could find no
Table 1. Activity of cystathionine $\beta$-synthase in PGR-13 and S. cerevisiae

The results represent the radioactivity of serine and cystathionine present in the reaction mixtures. The radioactivity of about 1000 c.p.m. at the cystathionine position came from a radioactive impurity present in our DL- $\left[{ }^{14} \mathrm{C}\right]$ serine preparation. Reaction mixtures contained $600 \mu \mathrm{g}$ and $550 \mu \mathrm{g}$ protein for PGR-13 and $S$. cerevisiae, respectively. The results from one representative experiment are presented. Similar ratios of cystathionine and serine were obtained in three experiments with extracts from independent cultures.

\begin{tabular}{llcc}
\hline \hline & & \multicolumn{2}{c}{ Radioactivity (c.p.m.) } \\
\cline { 3 - 4 } Strain & \multicolumn{2}{c}{ Spot } & \multicolumn{2}{c}{ Reaction mixture: } \\
& & + Homocysteine & - Homocysteine \\
\hline PGR-13 & Serine & 16265 & 14209 \\
& Cystathionine & 958 & 1345 \\
S. cerevisiae & Serine & 18241 & 18524 \\
& Cystathionine & 2657 & 960 \\
\hline \hline
\end{tabular}

activity of two enzymes of the reverse transsulphuration pathway: cystathionine $\beta$-synthase and cystathionine $\gamma$ lyase (Fig, 1, steps 5 and 6) while both activities were present in the reference yeast strains. In extracts from $S$. cerevisiae the activities of cystathionine $\beta$-synthase and cystathionine $\gamma$-lyase were 22 and $4 \mathrm{nmol} \mathrm{m^{-1 }}$ (mg protein $)^{-1}$, respectively.

$\beta$-Cystathionase and homocysteine synthase activities in extracts from PGR-13 were higher than those of $S$. cerevisiae (not shown).

Cystathionine $\beta$-synthase was first assayed as serine sulphydrylase with serine and sulphide as substrates, i.e. in a non-physiological reaction. We then assayed the reaction with homocysteine and serine, which are the natural substrates, using $S$. cerevisiae cell-free extract as the control (Table 1). It is evident that there was no activity of cystathionine $\beta$-synthase in PGR-13.

While it cannot be excluded that there is only one protein and one gene responsible for both of the activities lacking in PGR-13, we think this is highly improbable. A mutant of Yarrowia lipolytica has been described which has lost only one of these activities (Morzycka et al., 1976). A mutant of $S$. cerevisiae, cys3, with lowered activity of cystathionine $\gamma$-lyase (Ono et al., 1984) was tested in our laboratory and found to have a normal level of cystathionine $\beta$-synthase.

It was confirmed that the lack of transsulphurating activities observed in vitro was a real physiological trait by growth tests with selenate. Selenate is a toxic analogue of sulphate and competes with it for assimilation. When methionine is added together with selenate, it is methionine that serves as sulphur donor for synthesis of cysteine. Thus mutants blocked in the reverse trans- 
Table 2. Accumulation of ${ }^{35}$ S-labelled compounds in cells of $P G R-13$ and S. cerevisiae grown in the presence of $\mathrm{L}-\left[{ }^{35}\right.$ S $]$ methionine

The results from one representative experiment are given. A similar pattern was obtained in three experiments with extracts from independent cultures.

\begin{tabular}{|c|c|c|c|c|c|}
\hline \multirow[b]{2}{*}{ Strain } & \multicolumn{5}{|c|}{$\begin{array}{c}\text { Amount of }{ }^{35} \mathrm{~S} \text { or }{ }^{35} \mathrm{~S}-\mathrm{lab} e l l e d \\
{\left[\mu \mathrm{mol}(\mathrm{g} \text { dry wt })^{-1}\right]}\end{array}$} \\
\hline & $\begin{array}{l}\text { Total } \\
{ }^{35} S^{*}\end{array}$ & $\begin{array}{c}\text { Cysteine } \\
+ \\
\text { glutathione }\end{array}$ & $\begin{array}{l}\text { Homo- } \\
\text { cysteine }\end{array}$ & Methionine & $\begin{array}{l}S \text {-Adenosyl- } \\
\text { methionine }\end{array}$ \\
\hline PGR-13 & 113 & $1 \cdot 3$ & $2 \cdot 0$ & $53 \cdot 0$ & $31 \cdot 0$ \\
\hline S. cerevisiae & 181 & $22 \cdot 0$ & $4 \cdot 7$ & $66 \cdot 0$ & $43 \cdot 0$ \\
\hline
\end{tabular}

* Retained on Dowex $50\left(\mathrm{H}^{+}\right)$.

sulphuration pathway cannot grow on selenate/methionine medium. This feature allowed isolation of mutants devoid of either cystathionine $\gamma$-lyase or cystathionine $\beta$ synthase in Aspergillus nidulans (Pieniazek \& Paszewski, 1970) and Y. lipolytica (Morzycka et al., 1976). PGR-13 failed to grow on medium with $3 \mathrm{~mm}$-selenate $+1 \mathrm{~mm}$ methionine, whereas $S$. cerevisiae and $C$. utilis, used as controls, grew normally. When $1 \mathrm{mM}$-cysteine was used instead of methionine, it enabled PGR-13 to grow in the presence of selenate.

The ability of PGR-13 to catabolize methionine was tested directly in experiments with $\left.{ }^{35} S\right]$ methionine (Table 2). In $S$. cerevisiae, methionine was easily metabolized to cysteine while in PGR-13 it was metabolized only to a very limited extent. It should be noted that $17 \%$ of the ${ }^{35} \mathrm{~S}$ added to the growth medium was not in the form of methionine (see Methods). It is possible, therefore, that in the case of PGR-13 the radioactivity found in the cysteine and glutathione spots came from the non-methionine fraction of the radioactivity in the preparation used.

We conclude that PGR-13, presumably a new species, is the first yeast described so far which lacks the reverse transsulphuration pathway.

\section{Regulation of sulphur amino acid metabolism}

In all fungi tested, homocysteine synthase is under control of the same regulatory system as the enzymes of the sulphate assimilation pathway. In $S$. cerevisiae these enzymes are repressed, in a coordinate fashion, in the presence of methionine at concentrations less than $1 \mathrm{mM}$ (Breton \& Surdin-Kerjan, 1977). In PGR-13, addition of methionine to the growth medium at concentrations up to $5 \mathrm{~mm}$ had no effect on homocysteine synthase, while in the presence of $1 \mathrm{~mm}$-cysteine the enzyme specific
Table 3. Accumulation of ${ }^{35}$ S-labelled compounds in cells of $P G R-13$ and $S$. cerevisiae grown in the presence of ${ }^{35} \mathrm{SO}_{4}^{2-}$

The results from one representative experiment are presented. A similar pattern was obtained in three independent experiments. The content of $S$-adenosylmethionine was not determined precisely; it was lower than that of methionine.

\begin{tabular}{|c|c|c|c|c|c|}
\hline \multirow[b]{2}{*}{ Strain } & \multirow[b]{2}{*}{ Medium } & \multicolumn{4}{|c|}{$\begin{array}{l}\text { Amount of }{ }^{35} \mathrm{~S} \text { or }{ }^{35} \mathrm{~S} \text {-labelled compound } \\
{\left[\mu \mathrm{mol}(\mathrm{g} \text { dry wt })^{-1}\right]}\end{array}$} \\
\hline & & $\begin{array}{l}\text { Total } \\
{ }^{35} S^{*}\end{array}$ & $\begin{array}{c}\text { Cysteine } \\
+ \\
\text { glutathione }\end{array}$ & $\begin{array}{l}\text { Homo- } \\
\text { cysteine }\end{array}$ & Methionine \\
\hline PGR-13 & $\begin{array}{l}\text { GO } \\
\text { GO+ } \\
\text { L-Met } \\
(3 \mathrm{mM})\end{array}$ & $\begin{array}{l}6 \cdot 27 \\
5 \cdot 20\end{array}$ & $\begin{array}{l}4.06 \\
3.07\end{array}$ & $\begin{array}{l}0.58 \\
0 \cdot 25\end{array}$ & $\begin{array}{l}0 \cdot 71 \\
0 \cdot 41\end{array}$ \\
\hline S. cerevisiae & $\begin{array}{l}\text { GO } \\
\text { GO + } \\
\text { L-Met } \\
(3 \mathrm{mM})\end{array}$ & $\begin{array}{l}14 \cdot 30 \\
<0 \cdot 1\end{array}$ & $\begin{array}{l}6 \cdot 50 \\
\text { tr. }\end{array}$ & $\begin{array}{l}2 \cdot 20 \\
\text { tr. }\end{array}$ & $\begin{array}{l}0 \cdot 51 \\
\text { ND }\end{array}$ \\
\hline
\end{tabular}

ND, Not detected; tr., trace.

* Retained on Dowex $50\left(\mathrm{H}^{+}\right)$.

activity was lowered threefold $[360 \pm 17$ and $104 \pm 24 \mathrm{nmol} \mathrm{min}^{-1}$ (mg protein) $)^{-1}$ for cells grown without and with cysteine, respectively; means $\pm S D]$.

A marked difference was also observed between PGR13 and $S$. cerevisiae in the effect of methionine on sulphate assimilation and the synthesis of sulphur amino acids (Table 3). While the de novo synthesis of amino acids from sulphate was completely repressed in the $S$. cerevisiae strain grown in the presence of methionine, this amino acid had only a slight effect in PGR-13. Similarly, only a slight effect of cysteine on sulphate assimilation in PGR-13 was observed (not shown). This contrasts with the relatively strong repressing effect of cysteine on homocysteine synthase in this strain.

Neither methionine nor cysteine affected the level in PGR-13 of $\beta$-cystathionase, an enzyme of methionine biosynthesis, (Fig. 1, step 3).

Both $S$. cerevisiae and PGR-13 grown in the presence of methionine accumulated high pools of methionine and $S$-adenosylmethionine (Table 2). It seems clear that the regulation of the sulphate assimilation pathway and homocysteine synthase in PGR-13 is not mediated by these compounds, contrary to what has been suggested for S. cerevisiae (Cherest et al., 1975). The absence of methionine repression in PGR-13 is logical, as the presence of such a regulatory mechanism in a strain unable to catabolize this amino acid to cysteine would be lethal.

Our results suggest that cysteine may be a lowmolecular-mass effector in the regulation. It is perhaps 
the regulatory role of cysteine that is a particular trait of the unusual metabolism in PGR-13. It is possible, however, that cysteine may play a similar role in $S$. cerevisiae since cysteine can be readily synthesized from methionine. In fact, the pool of cysteine is much higher in methionine-grown than in sulphate-grown cells (Tables 2 and 3 ).

This work was supported within the project CPBR 3.13 and was partially supported by the UNIDO project DP/POL/87/001.

We are grateful to Dr B. Ono for supplying the cys3 strain of $S$. cerevisiae.

\section{References}

Barnett, J. A., Payne, R. W. \& Yarrow, D. (1983). Yeasts, Characteristics and Identification. Cambridge: Cambridge University Press.

BRADFORD, M. M. (1976). A rapid and sensitive method for the quantitation of microgram quantities of protein utilising the principle of protein-dye binding. Analytical Biochemistry 18, 248254.

BREton, A. \& Surdin-KerJan, Y. (1977). Sulphate uptake in Saccharomyces cerevisiae: biochemical and genetic study. Journal of Bacteriology 132, 428-435.

Cherest, H., Surdin-KerJan, Y. \& de Robichon-Szulmajster, H. (1975). Methionine- and $S$-adenosylmethionine-mediated repression in methionyl-transfer ribonucleic acid synthetase mutant of Saccharomyces cerevisiae. Journal of Bacteriology 123, 428-435.
Morzycka, E., Sawnor-Korszynska, D., Paszewski, A., Grabski, J. \& RACZYNSKA BoJanowsKa, J. (1976). Methionine overproduction by Saccharomycopsis lipolytica. Journal of Applied and Environmental Microbiology 32, 125-130.

Ono, B., Suruga, T., Yamamoto, M., Mutata, K., Kimura, A., SHINODA, S. \& OHMORI, S. (1984). Cystathionine accumulation in Saccharomyces cerevisiae. Journal of Bacteriology 158, 860-865.

PASZEWSKI, A. \& GRABSKI, J. (1973). Studies on $\gamma$-cystathionase and $O$ acetylhomoserine sulfhydrylase as the enzymes of alternative biosynthetic pathway in Aspergillus nidulans. Acta Biochimica Polonica 20, 159-168.

Paszewski, A. \& Grabski, J. (1974). Regulation of S-amino acids biosynthesis in Aspergillus nidulans. Molecular and General Genetics 132, 307-320.

Paszewski, A., Prazmo, W., Nadolska, J. \& Regulski, M. (1984). Mutations affecting the sulphur assimilation pathway in Aspergillus nidulans: their effect on sulphur amino acid metabolism. Journal of General Microbiology 130, 1113-1121.

Pieniazek, N. J. \& Paszewski, A. (1970). The use of media containing sodium selenate for selecting mutants of Aspergillus nidulans. Aspergillus News Letter 11, 12.

Pieniazek, N. J., Stepien, P. P. \& Paszewski, A. (1973). Aspergillus nidulans mutant lacking cystathionine synthase. Biochimica et Biophysica Acta 297, 34-47.

Piotrowska, M. \& Paszewski, A. (1986). Propargylglycine as a fungal inhibitor: effect on sulphur amino acid metabolism. Journal of General Microbiology 132, 2753-2760.

Swietlinska, Z., Zaborowska, D., Haladus, E. \& ZuK, J. (1978). Study on liquid holding recovery in DEB-inactivated rad-3 mutant of Saccharomyces cerevisiae. Molecular and General Genetics 166, 97107.

WIEBERS, J. L. \& GARNER, Y. (1967). Acyl derivatives of homoserine as substrate for homocysteine synthesis in Neurospora crassa, yeast, and Escherichia coli. Journal of Biological Chemistry 242, 5644-5649. 